\title{
PENGARUH MODEL PEMBELAJARAN SNOWBALL THROWING BERBANTUAN MEDIA VIDEO TERHADAP KOMPETENSI PENGETAHUAN PPKn SISWA KELAS V SD GUGUS III KECAMATAN KUTA UTARA TAHUN AJARAN 2018/2019
}

\author{
I Putu Endra Aditya ${ }^{1}$, I G.A. Agung Sri Asri ${ }^{1}$, I Ketut Ardana ${ }^{2}$ \\ ${ }^{1}$ Jurusan Pendidikan Dasar, Universitas Pendidikan Ganesha, Singaraja, Indonesia \\ 2Jurusan Pendidikan Guru Sekolah Dasar, Universitas Pendidikan Ganesha, Singaraja, Indonesia
}

\begin{abstract}
Abstrak
Penelitian ini bertujuan untuk mengetahui pengaruh model pembelajaran Snowball Throwing berbantuan media video terhadap kompetensi pengetahuan PPKn siswa kelas V SD Gugus III Kecamatan Kuta Utara tahun ajaran 2018/2019. Jenis penelitian ini adalah penelitian eksperimen semu, dengan desain nonequivalent control group design. Seluruh kelas V SD Gugus III Kecamatan Kuta Utara tahun 2018/2019 sebanyak 14 kelas terdiri dari 522 siswa dijadikan sebagai populasi penelitian. Sampel ditentukan dengan menggunakan teknik random sampling dengan mengacak kelas. Sampel dalam penelitian ini adalah kelas VC SD No. 1 Kerobakan sebagai kelompok eksperimen dengan sebanyak 31 siswa dan kelas VA SD No.2 Kerobokan Kaja sebagai kelompok kontrol sebanyak 30 siswa . Data kompetensi pengetahuan PPKn dikumpulkan dengan instrumen berupa tes objektif bentuk pilihan ganda biasa berjumlah 30 butir tes yang telah divalidasi. Data kompetensi pengetahuan PPKn dianalisis dengan uji-t polled varian. Berdasarkan hasil analisis uji-t diperoleh $t_{\text {hitung }}=4,787$. Harga tersebut kemudian dibandingkan dengan harga tabel dengan $\mathrm{dk}=59$ dan taraf signifikansi $5 \%$ sehingga diperoleh harga $t_{\text {tabel }}=2,000$ berarti $\mathrm{H}_{\mathrm{o}}$ ditolak, karena thitung $=$ $4,787>t_{\text {tabel }}=2,000$. Demikian pula rerata kompetensi pengetahuan PPKn siswa kelompok eksperimen $\overline{\boldsymbol{X}}=0,204>\overline{\boldsymbol{X}}=0,126$ rerata kompetensi pengetahuan PPKn siswa kelompok kontrol.Dengan demikian dapat disimpulkan, model pembelajaran Snowball Throwing berbantuan media video berpengaruh terhadap kompetensi pengetahuan PPKn siswa kelas V SD Gugus III Kecamatan Kuta Utara tahun ajaran 2018/2019. Berdasarkan hasil penelitian ini disarankan kepada peneliti lain dapat dijadikan kajian yang relevan khususnya sebagai referensi bagi peneliti dengan kajian yang luas dan memper dalam teori mengenai model pembelajaran Snowball Throwing berbantuan media video.

Keywords:

snowball throwing, media video, PPKn
\end{abstract}

\section{Pendahuluan}

Pendidikan merupakan sarana penting untuk meningkatkan kualitas Sumber Daya Manusia dalam menjamin keberlangsungan pembangunan suatu bangsa. Peningkatan sumber daya manusia jauh lebih mendesak untuk segera direalisasikan terutama dalam menghadapi era persaingan global. Peningkatan kualitas Sumber Daya Manusia sejak dini merupakan hal yang penting yang harus dilakukan secara sungguh-sungguh. Dalam perkembangan zaman seperti 
inilah dibutuhkan sumber daya manusia yang berkualitas agar dapat bersaing di dunia kerja nasional maupun internasional.

Pendidikan di Indonesia terdiri dari beberapa jenjang salah satunya jenjang sekolah dasar, dimana sekolah dasar merupakan jenjang yang paling dasar dalam pendidikan formal di Indonesia. Oleh Karena itu pembelajaran yang diberikan di sekolah dasar harus terencana sebaik mungkin agar terbentuk konsep dasar siswa yang kuat. Pembelajaran adalah sebuah proses interaksi antara peserta didik dengan pendidik dan sumber belajar pada suatu lingkungan belajar yang meliputi guru dan siswa yang saling bertukar informasi. Sebuah keberhasilan dan kegagalan peserta didik dalam mengikuti pelajaran di sekolah dasar akan sangat menentukan masa depannya dalam jenjang yang lebih tinggi lagi dan khususnya di daerah Bali, sehingga perlunya upaya dalam meningkatkan dan mengembangkan pembelajaran di sekolah dasar. Peningkatan kualitas pembelajaran banyak ditentukan oleh perancangan pembelajaran yang dilakukan oleh guru. Sehingga guru diharapkan mampu menciptakan suatu proses pembelajaran yang aktif dan tidak membosankan. Guru dapat menggunakan model pembelajaran yang bervariasi, sehingga menumbuhkahkan motivasi siswa untuk belajar.

Kurikulum 2013 merupakan kurikulum yang saat ini diimplementasikan di Indonesia yang merupakan penyempurnaan terhadap Kurikulum Tingkat Satuan Pendidikan (KTSP). Kurikulum 2013 bertujuan untuk mempersiapkan manusia Indonesia agar memiliki kemampuan hidup sebagai pribadi dan warga negara yang beriman, produktif, kreatif, inovatif, dan afektif serta mampu berkontribusi pada kehidupan bermasyarakat, berbangsa, bernegara, dan peradaban dunia.

Penerapan kurikulum 2013 pada tingkat sekolah dasar menggunakan tematik terpadu dan diimplementasikan dengan menggunakan pendekatan saintifik dengan tematik terpadu yaitu mengaitkan beberapa mata pelajaran ke dalam sebuah tema. Sebuah tema terdiri dari beberapa subtema, dalam subtema tersebut terdiri dari 6 pembelajaran. Mata pelajaran seperti Bahasa Indonesia, PPKn, Matematika, IPA, IPS, Penjaskes, dan SBdP dipadukan dalam kegiatankegiatan pembelajaran dalam suatu tema. Pemaduan mata pelajaran dalam kegiatan pembelajaran tersebut, bertujuan agar siswa tidak menyadari sedang mempelajari mata pelajaran tertentu, sehingga diharapkan siswa dapat memahami suatu konsep dengan utuh bukan hanya sebagai pengetahuan tetapi juga diterapkan melalui kegiatan-kegiatan dalam pembelajaran dan kehidupan sehari-hari.

Pendidikan Pancasila dan Kewarganegaraan dapat menumbuhkan semangat perjuangan bangsa yang merupakan kekuatan mental spiritual telah melahirkan mental yang luar biasa dalam masa perjuangan fisik dalam perjuangan memerdekakan Negara oleh para pahlawan terdahulu, sedangkan dalam menghadapi globalisasi untuk mengisi kemerdekaan kita memerlukan perjuangan nonfisik sesuai dengan bidang profesi masing-masing. Perjuangan ini dilandasi dengan nilai-nilai perjuangan bangsa sehingga kita tetap memiliki wawasan dan kesadaran bernegara, sikap dan perilaku yang cinta tanah air dan mengutamakan persatuan serta persatuan bangsa dalam rangka bela negara demi tetap utuh dan tegaknya NKRI.

Kompetensi atau kemampuan yang diharapkan dari pendidikan pancasila dan kewarganegaraan agar kita memiliki wawasan kesadaran bernegara untuk bela negara dan memiliki pola pikir, pola sikap dan perilaku sebagai pola tindak dan cinta tanah air berdasarkan pancasila.

Tujuan utama pendidikan pancasila dan kewarganegaraan adalah untuk menumbuhkan cinta tanah air dan bersendikan kebudayaan, wawasan Nusantara serta ketahanan nasional dalam diri para siswa sebagai calon penerus bangsa.

\section{Metode}

Penelitian ini dilaksanakan di Gugus III Kecamatan Kuta Utara. Adapun seluruh SD yang tergabung di Gugus III Kecamatan Kuta Utara yaitu, (1) SD Negeri 1 Kerobokan, (2) SD Negeri 2 Kerobokan, (3) SD Negeri 3 Kerobokan, (4) SD Negeri 4 Kerobokan, (5) SD Negeri 1 Kerobokan Kaja, (6) SD Negeri 2 Kerobokan Kaja, (7) SD Negeri 3 Kerobokan Kaja, (8) SD Kalam Kudus. Pembelajaran dilaksanakan di ruang kelas V. Waktu penelitian diadakan pada semester 2 tahun 
ajaran 2018/2019. Penyusunan proposal laporan penelitian di mulai dari bulan Januari sampai bulan Mei 2019.

Kegiatan yang dilakukan selama penelitian dimulai dari pengajuan judul proposal, revisi judul, penyusunan proposal, bimbingan proposal, seminar proposal, revisi proposal, persiapan penelitian, pengumpulan data, analisis data, penyusunan skripsi dan ujian skripsi. Penelitian yang akan dilaksanakan ini menggunakan pendekatan penelitian kuantitatif, yaitu menggunakan desain ekperimen semu (quasi experiment design). Hal ini dikarenakan tidak semua variabel yang muncul dalam eksperimen dapat diatur dan dikontrol secara ketat. (Sugiyono, 2017). Adapun rancangan desain eksperimen semu yang dipilih, yaitu Nonequivalent Control Group Design. Bentuk rancangan ini dapat digambarkan sebagai berikut.

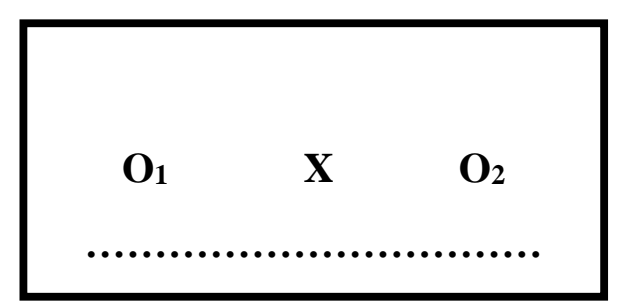

Gambar 1

Desain Penelitian Nonequivalent Control Group Design

(Sumber: Sugiyono, 2017:79)

Subjek dalam penelitian ini meliputi populasi dan sampel. Populasi dalam suatu penelitian perlu ditetapkan dengan tujuan agar penelitian yang dilakukan benar-benar mendapatkan data sesuai yang diharapkan. Sugiyono (2017:80) mengemukakan "Populasi adalah wilayah generalisasi yang terdiri atas: objek/subjek yang mempunyai kualitas dan karakteristik tertentu yang ditetapkan oleh peneliti untuk dipelajari dan kemudian ditarik kesimpulannya." Populasi dalam penelitian ini adalah seluruh siswa kelas V SD Gugus III Kecamatan Kuta Utara Tahun Ajaran 2018/2019, yang terdiri dari 14 sekolah dasar negeri. Jumlah populasi dari penelitian ini adalah 522 siswa. Setelah mendata seluruh populasi penelitian, selanjutnya dilakukan penentuan sampel. "Menurut Sugiyono (2017:81), "Sampel adalah bagian dari jumlah dan karakteristik yang dimiliki oleh populasi tersebut". Pernyataan yang serupa juga disampaikan Agung (2014:69) bahwa "Sampel ialah sebagian dari populasi yang diambil, yang dianggap mewaliki seluruh populasi dan diambil dengan menggunakan teknik tertentu". Sedangkan menurut Setyosari (2015:221), "sampel merupakan sejumlah kelompok kecil yang mewakili populasi untuk dijadikan sebagai objek penelitian". Sehingga dapat dirangkum bahwa sampel merupakan bagian atau kelompok kecil dari jumlah dan karakteristik yang dimiliki populasi yang dianggap representatif (mewakili) yang diambil dengan teknik tertentu. Teknik pengambilan sampel pada penelitian ini yaitu Random Sampling. Random sampling adalah "pengambilan anggota sampel dari populasi dilakukan secara acak tanpa memperhatikan strata yang ada dalam populasi itu" (Sugiyono,2016a:82). Teknik random sampling dalam penelitian ini dilakukan dengan pengacakan kelas yang telah ada sebelumnya. Pengacakan kelas dilakukan karena sampel tersedia dalam bentuk kelas yang mengakibatkan peneliti tidak dapat melakukan pengacakan individu dan membentuk kelas baru. Penentuan sampel dalam penelitian ini dilakukan dengan cara pengundian kelas. Nama kelas V di semua SD populasi ditulis pada masing-masing kertas dan setiap kertas tersebut digulung dan dimasukkan ke dalam botol. Setelah itu dilakukan pengocokan dan kemudian diambil 2 gulungan kertas. Nama kelas dari masing-masing SD pada gulungan kertas itu merupakan sampel penelitian. Setelah menetukan sampel dari penelitian selanjutnya dilakukan pretest. Hasil pretest akan dianalisis menggunakan uji man witney karena data tidak normal. Sebelum melakukan uji man 
witney akan dilakukan uji normalitas dan homogenitas sebaran data . Uji normalitas sebaran data dilakukan dengan menggunakan Kolmogorov Smirnov. Berdasarkan hasil undian, diperoleh kelas VC SD No.1 Kerobokan sebagai kelompok eksperimen dan kelas V SD No.2 Kerobokan sebagai kelompok kontrol. Metode pengumpulan data merupakan cara-cara yang digunakan untuk mengumpulkan data dalam suatu penelitian. Dalam penelitian ini, metode pengumpulan data yang digunakan yaitu metode tes. "Test adalah alat atau prosedur yang dipergunakan dalam rangka pengukuran dan penilaian" (Sudijono, 2013:66). "Tes adalah sejumlah pertanyaan yang diajukan oleh evaluator secara lisan atau tertulis yang harus dijawab oleh peserta tes (testee) dalam bentuk lisan atau tulisan" (Supardi, 2015:9). Metode tes dalam penelitian ini digunakan untuk mendapatkan data mengenai kompetensi pengetahuan PPKn siswa. Instrumen pengumpulan data dalam penelitian ini adalah tes objektf. Tes objektif adalah tes yang dalam pemeriksaannya dapat dilakukan secara objektif (Arikunto, 2013). Tes objektif dalam penelitian ini berbentuk tes objektif pilihan ganda biasa. Tes objektif dalam penelitian ini terdiri dari 30 butir soal dan dalam penskoran tes setiap soal disertai dengan empat alternatif jawaban yang dipilih siswa (alternatif a, b, c, d). Setiap soal diberikan skor 1 bila siswa menjawab dengan benar sedangkan skor 0 untuk siswa yang menjawab salah pada tiap butir tes.

Sebelum dilakukan penyebaran tes, maka tes terlebih dahulu di uji coba. Uji coba instrumen pengumpulan data yang dilakukan dalam penelitian ini meliputi uji validitas, uji daya beda, uji tingkat kesukaran, dan uji reliabilitas. Adapun uji validitas instrumen yang akan dilakukan sebagai berikut. (1) Validitas isi, "Suatu tes dikatakan valid dari segi isinya apabila mengukur tujuan khusus tertentu yang sejajar dengan materi atau isi pelajaran yang diberikan" (Arikunto, 2013:82). Sebuah butir instrumen penilaian dikatakan memiliki validitas isi apabila mengukur tujuan khusus sejajar dengan materi atau isi pelajaran yang di berikan (Supardi, 2015: 98). (2) Validitas item, keadaan di mana suatu item mempunyai dukungan yang besar terhadap skor total (Arikunto, 2013). Validitas item dapat ditentukan jika suatu instrumen telah diujicobakan. Validitas item pada penelitian ini ditentukan dengan menggunakan teknik korelasi point biserial (rpbi). Uji Daya Beda, Untuk menentukan butir soal yang tepat dalam suatu penelitian, harus diketahui bahwa soal tersebut mempunyai daya beda yang baik terhadap siswa yang berbeda. Menurut Arikunto (2013: 226) daya pembeda soal, adalah kemampuan sesuatu soal untuk membedakan antara siswa yang pandai (berkemampuan tinggi) dengan siswa yang bodoh (berkemampuan rendah). Jika D bernilai negatif, semuanya tidak baik. jadi semua butir soal yang mempunyai nilai D negatif sebaiknya dibuang saja (Arikunto, 2013: 232). Uji Tingkat Kesukaran, Kebaikan suatu tes juga akan ditentukan oleh tingkat kesukaran masing-masing item. Item yang terlalu mudah atau item yang terlalu sukar merupakan hal yang tidak baik. Menurut Arikunto (2013) soal yang baik adalah soal yang tidak terlalu mudah atau tidak terlalu sukar. Terdapat syarat terakhir dalam pengujian instrumen, yaitu reliabilitas. "Suatu tes dikatakan memiliki reliabilitas tinggi, jika tes tersebut memberikan hasil yang tetap atau ajeg." (Agung, 2013:82). Arikunto (2016: 100) mengatakan bahwa reliabilitas berhubungan dengan masalah kepercayaan. Reliabilitas instrumen penelitian kemampuan membaca pemahaman diuji dengan menggunakan rumus Kuder Richadson (KR-20).

Data yang terkumpul dalam pelaksanaan penelitian ini perlu untuk dianalisis. Teknik analisis yang digunakan untuk menganalisis data hasil penelitian adalah teknik analisis statistik inferensial. Analisis statistik inferensial yang digunakan dalam penelitian ini adalah uji t $(t$-test) . Dalam penelitian ini, uji normalitas sebaran data ditentukan dengan menggunakan Kolmogorov Smirnov dan Uji homogenitas varians dalam penelitian ini menggunakan uji F. Jika sudah memenuhi uji prasyarat analisis yaitu uji normalitas sebaran data dan uji homogenitas varians. Maka data selanjutnya dianalisis dengan statistik parametrik.

\section{Hasil dan Pembahasan}

Data yang dideskripsikan pada hasil penelitian ini adalah data hasil tes kompetensi pengetahuan PPKn siswa kelas V pada kelompok eksperimen dan kelompok kontrol. Setelah 
dilakukan pengundian sampel yang setara, keseluruhan siswa kelas VA SD No. 2 Kerobokan Kaja ditetapkan sebagai kelas kontrol dan keseluruhan siswa kelas VC SD No. 1 Kerobokan ditetapkan sebagai kelas eksperimen. Kelas kontrol dibelajarkan secara konvensional sebanyak 6 kali, sedangkan pada kelas eksperimen diberi perlakuan berupa model pembelajaran Snowball Throwing berbantuan media video sebanyak 6 kali. Data hasil kompetensi pengetahuan PPKn siswa diperoleh dari hasil posttest yang diberikan pada akhir penelitian. Instrumen yang digunakan untuk mengumpulkan data adalah tes pilihan ganda biasa. Deskripsi data hasil kompetensi pengetahuan PPKn siswa yang dipaparkan meliputi nilai rerata, standar deviasi, dan varians. Berdasarkan hasil analisis kompetensi pengetahuan PPKn nilai rata-rata siswa kelompok eksperimen $=0,204$, standar deviasi $=0,069$, dan varians $=0.004737$ dibandingkan dengan tabel klarifikasi interpretasi gain skor ternormalisasi pengkatagorian kompetensi pengetahuan PPKn, sehingga dapat diketahui kompetensi pengetahuan PPKn siswa kelompok eksperimen berada pada kategori Cukup. Sedangkan nilai rata-rata siswa kelompok kontrol = 0,126 , standar deviasi $=0,057$, dan varians $=0,003239$ dibandingkan dengan tabel klarifikasi interpretasi gain skor ternormalisasi pengkatagorian kompetensi pengetahuan PPKn sehingga dapat diketahui kompetensi pengetahuan PPKn siswa kelompok eksperimen berada pada kategori Cukup. Uji prsyarat dalam penelitian dilakukan sebagai syarat dipergunakannya statistik parametrik seperti pengujian hipotetsis dengan menggunakan uji-t. uji prasyarat tersebut terdiri dari uji normalitas sebaran data dan uji homogenitas varians. Uji normalitas sebaran data dilakukan untuk mengetahui sebaran frekuensi skor. Uji normalitas dalam penelitian ini dilakukan

dengan menggunakan rumus Kolmogorov Smirnov. Kriteria pengujian pada taraf siginifikansi $5 \%$ dan derajat kebebasannya $\mathrm{n}-1$ adalah jika $\mathrm{F}_{\text {hitung }}<\mathrm{F}_{\text {tabel, }}$ maka data berdistribusi normal, sedangkan $F_{\text {hitung }} \geq F_{\text {tabel, }}$, maka sebaran data tidak berdistribusi normal (Sugiyono, 2017).

Berdasarkan hasil uji normalitas kelompok eksperimen, diperoleh $F_{\text {hitung }}=0,166$. Nilai tersebut kemudian dibandingkan dengan $\mathrm{F}_{\text {tabel }}$ pada taraf signifikansi $5 \%\left(\mathrm{~F}_{\text {tabel }}=0,244\right)$, sehingga didapat hasil $\mathrm{F}_{\text {hitung }}<\mathrm{F}_{\text {tabel }}(0,166<0,244)$ yang berarti bahwa data berdistribusi normal.

Bedasarkan uji normalitas kelompok kontrol, diperoleh $F_{\text {hitung }}=0,137$, kemudian dibandingkan dengan $\mathrm{F}_{\text {tabel }}$ pada taraf signifikansi $5 \%\left(\mathrm{~F}_{\text {tabel }}=0,248\right)$, dan didapat hasil $\mathrm{F}_{\text {hitung }}$ $<\mathrm{F}_{\text {tabel }}(0,137<0,248)$ yang berarti bahwa data berdistribusi normal. Uji homogenitas varians dilakukan untuk menunjukkan bahwa dua atau lebih kelompok data sampel berasal dari populasi yang memiliki varians yang sama sehingga perbedaan yang terjadi dalam uji hipotesis benar-benar terjadi akibat adanya perbedaan antara kelompok, bukan akibat dari adanya perbedaan dalam kelompok. Uji homogenitas varians dalam penelitian ini menggunakan uji F. Berdasarkan hasil uji homogenitas varians, diperoleh $\mathrm{F}_{\text {hitung }}=1.462656$. Nilai tersebut kemudian dibandingkan dengan $\mathrm{F}_{\text {tabel }}$ pada taraf signifikansi 5\% dengan derajat kebebasan pembilang = 31 $-1=30$ dan derajat kebebasan penyebut $=30-1=29,\left(F_{\text {tabel }}=1.854293\right)$, sehingga didapat hasil $\mathrm{F}_{\text {hitung }}<\mathrm{F}_{\text {tabel }}(1.462656<1.854293)$ yang berarti data homogen. Berdasarkan hasil uji prasyarat yang terdiri dari uji normalitas sebaran data dan uji homogenitas varians, disimpulkan bahwa data kedua kelompok sampel ialah berdistribusi normal dan memiliki varians yang homogen. Dengan demikian, uji hipotesis menggunakan uji-t dapat dilakukan. Hipotesis yang diuji dalam penelitian ini adalah terdapat pengaruh model pembelajaran Snowball Throwing berbantuan media video terhadap kompetensi pengetahuan PPKn kelas V SD Gugus III Kecamatan Kuta Utara Tahun Ajaran 2018/2019. Hasil uji prasyarat yang meliputi uji normalitas sebaran data dan uji homogenitas varians menunjukkan bahwa data kedua kelompok sampel ialah berdistribusi normal dan memiliki varians yang homogen, sehingga dapat menggunakan analisis statistik parametrik. Analisis statistik parametrik yang digunakan yaitu uji-t dengan polled varians.

Berdasarkan hasil uji-t, diperoleh $t_{\text {hitung }}=4.787$. Nilai tersebut kemudian dibandingkan dengan $t_{\text {tabel }}$ pada taraf signifikansi $5 \%$ dengan derajat kebebasan $=59\left(t_{\text {tabel }}=2,000\right)$, dan 
didapat hasil $t_{\text {hitung }}>t_{\text {tabel }}(4,787>2,000)$ sehingga Ho ditolak, Berikut disajikan rekapitulasi hasil analisis data dengan menggunakan uji t pada tabel 1.

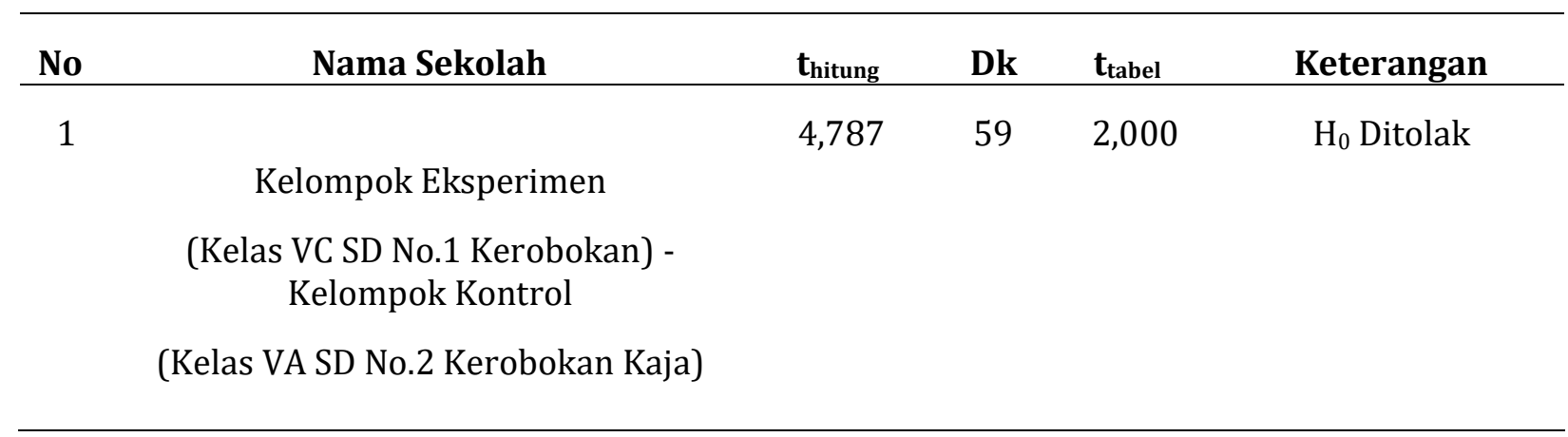

Tabel 1.

Rekapitulasi analisis uji t

Berdasarkan hasil uji-t, diperoleh bahwa $t_{\text {hitung }}=4,787$ yang kemudian dibandingkan dengan $t_{\text {tabel }}$ pada taraf signifikansi $5 \%$ dan derajat kebebasan $59\left(t_{\text {tabel }}=2,000\right)$. Dari perhitungan tersebut, diperoleh $t_{\text {hitung }}>t_{\text {tabe }} l(4,787>2,000)$, sehingga Ho ditolak, yang berarti terdapat perbedaan yang signifikan kompetensi pngetahan PPKn antara kelompok siswa yang dibelajarkan dengan model pembelajaran Snowball Throwing berbantuan media video dan kelompok siswa yang dibelajarkan dengan pembelajaran konvensional. Dengan demikian disimpulkan bahwa terdapat pengaruh model pembelajaran Snowball Throwing berbantuan media video terhadap kompetensi pengetahuan PPKn siswa kelas V SD Gugus III Kecamatan Kuta Utara Tahun Ajaran 2018/2019. Rata-rata kompetensi pengetahuan siswa kelompok yang dibelajarkan dengan model pembelajaran Snowball Throwing berbantuan media video yaitu 0,204. sehingga rata-rata nilai kelompok eksperimen dapat dikategorikan cukup. Sedangkan, 
rata-rata kemampuan membaca pemahaman siswa kelompok yang dibelajarkan pembelajaran konvensional yaitu 0,126. Sehingga rata-rata nilai kelompok kontrol dapat dikategorikan cukup. Pengkatagorian kompetensi pengetahuan PPKn, sehingga dapat diketahui kompetensi pengetahuan PPKn siswa kelompok eksperimen berada pada kategori Cukup Namun, dilihat perolehan nilai rata-rata, kelompok eksperimen memiliki rata-rata lebih tinggi daripada kelompok kontrol. Hal ini berarti model pembelajaran Snowball Throwing memiliki pengaruh yang lebih baik terhadap kompetensi pengetahuan PPKn siswa dilihat dari perolehan nilai ratarata antara kelompok eksperimen dan kelompok kontrol.

Pada kelompok eksperimen, kegiatan pembelajaran dalam menggunakan model pembelajaran Snowball Throwing berbantuan media video berlangsung dengan kondusif dan menyenangkan. Siswa menjadi aktif dan bersemangat dalam pembelajaran karena pembelajaran dengan model pembelajaran Snowball Throwing berbantuan media video difokuskan pada permasalahan yang dialami oleh kebanyakan siswa. Berbantuan media video mempermudah siswa dalam proses pemecahan masalah.. Selain itu, dalam pembelajaran melalui model pembelajaran Snowball Throwing berbantuan media video siswa mampu bekerjasama dengan kelompok dalam memecahkan masalah yang ditemukan serta mengemukakan pendapat mengenai cara pemecahan masalah tersebut. Dari berbagai kegiatan yang dilakukan selama pembelajaran, terlihat bahwa siswa memiliki minat dan motivasi yang tinggi untuk mengikuti pembelajaran dengan baik. Dalam kelompok kontrol, kegiatan pembelajaran dilakukan secara konvensional sehingga pembelajaran berlangsung kurang bermakna untuk siswa. Hal ini mengakibatkan kurangnya kesempatan siswa untuk melatih kepercayaan diri dan berfikir secara kritis.. Selain itu kurangnya penggunaan media pembelajaran mengakibatkan materi yang disampaikan guru kurang dipahami oleh siswa, akibatnya, siswa sulit memahami materi yang disampaikan dan merasa cepat bosan. Kegiatan pembelajaran menggunakan model pembelajaran Snowball Throwing berbantuan media video memberikan pengaruh terhadap kompetensi pengetahuan PPKn. pemahaman siswa kearah yang lebih baik karena model pembelajaran Snowball Throwing berbantuan media video memiliki kelebihan dalam kegiatan pembelajaran dengan mengajak siswa untuk aktif dalam memecahkan masalah. Model pembelajaran Snowball Throwing merupakan suatu model pembelajaran yang diterapkan dengan melempar segumpalan kertas untuk menunjuk siswa yang diharuskan menjawab soal dari guru (Huda, 2014). Sedangkan pendapat Sohimin (2014) yang menyatakan bahwa model pembelajaran Snowball Throwing adalah sangat tepat untuk meningkatkan kepercayaan diri siswa serta mampu berfikir secara kritis dalam menyelesaikan soal secara diskusi dan merupakan bagian dari model pembelajaran kooperatif". Hanya saja, pada model ini kegiatan belajar diatur sedemikian rupa sehingga proses belajar mengajar dapat berlangsung dengan lebih menyenangkan. Berdasarkan pendapat diatas dapat disimpulkan bahwa model pembelajaran snowball throwing merupakan model pembelajaran yang mampu melibatkan siswa secara aktif dalam berbagai aktifitas belajar sehingga siswa dapat menggali pengetahuannya, menyusun gagasannya, mengkonstruksi gagasan baru. Perbedaan kompetensi pengetahuan PPKn siswa dapat terlihat dari langkah pembelajaran yang dilakukan pada kedua kelompok tersebut, hasil analisis uji hipotesis, dan nilai rata-rata kelompok siswa yang mengikuti pembelajaran menggunakan model pembelajaran Snowball Throwing dengan kelompok siswa yang mengikuti pembelajaran konvensional. Hasil temuan pada penelitian ini memiliki persamaan dengan penelitian sebelumnya yang relevan dan memperkuat hasil penelitian yang diperoleh, yaitu penelitian yang dilakukan hal tersebut didukung oleh Sudana (2017) terdapat perbedaan yang signifikan antara kelompok siswa yang dibelajarkan dengan model pembelajaran Snowball Throwing dan kelompok yang mengikuti pembelajaran dengan model pembelajaran konvensional siswa kelas V SD di Gugus IV Kecamatan Kubu yang dibuktikan dengan $t_{\text {hitung }}=6,60>t_{\text {tabel }}=2,021$. Persamaan penelitian tersebut dengan penelitian yang akan dilaksanakan ini terletak pada model pembelajaran yang diterapkan. Adapun perbedaannya yaitu, (a) penelitian tersebut berbantuan media power point, sedangkan penelitian yang akan dilaksanakan ini berbantuan media video (b) penelitian tersebut dapat berpengaruh terhadap hasil belajar IPA siswa kelas V, sedangkan penelitian yang akan 
dilaksanakan ini diharapkan berpengaruh terhadap kompetensi pengetahuan PPKn siswa kelas V.

Berdasarkan hasil dan pembahasan tersebut disimpulkan bahwa terdapat pengaruh model pembelajaran snowball Throwing berbantuan media video terhadap kompetensi pengetahuan PPKn siswa kelas V SD Gugus III Kuta Utara Tahun Ajaran 2018/2019.

\section{Simpulan}

Kompetensi Pengetahuan PPKn kelompok yang dibelajarkan menggunakan model pembelajaran snowball throwing berbantuan media video pada siswa kelas V SD Gugus III Kecamatan Kuta Utara Tahun Ajaran 2018/2019. Diperoleh rata-rata gain skor ternormalisasi 0,24, rata-rata tersebut dikonversikan berdasarkan klasifikasi gain skor ternormalisasi, sehingga dapat diketahui bahwa kompetesi pengetahuan PPKn siswa pada kelompok eksperimen termasuk dalam kategori cukup. Kompetensi Pengetahuan PPKn kelompok yang dibelajarkan menggunakan pembelajaran konvensional pada siswa kelas V SD Gugus III Kecamatan Kuta Utara Tahun Ajaran 2018/2019. Diperoleh rata-rata gain skor ternormalisasi 0,126, rata-rata tersebut dikonversikan berdasarkan klasifikasi gain skor ternormalisasi, sehingga dapat diketahui bahwa kompetesi pengetahuan PPKn siswa pada kelompok eksperimen termasuk dalam kategori cukup.Terdapat pengaruh model pembelajaran snowball throwing berbantuan media video terhadap kompetensi pengetahuan PPKn. Hal ini dibuktikan dengan hasil analisis uji-t diperoleh $\mathrm{t}_{\text {hitung }}=4,787315233$ pada taraf signifikansi $5 \%$ dengan $\mathrm{dk}=59$ diperoleh nilai tabel $=2,000995378$ sehingga $t_{\text {hitung }}=4,787315233>\mathrm{t}$ tabel $=2,000995378$ gain skor ternomalisasi kompetensi pengetahuan PPKn kelompok eksperimen $\frac{\bar{X}}{X}=0,24>\frac{\bar{X}}{X}=0,126$ ratarata gain skor kompetensi pengetahuan PPKn kelompok kontrol. Adapun saran yang dapat disampaikan setelah dilaksanakan dan diperoleh hasil dari penelitian ini yaitu : (1) Bagi guru. Guru agar penelitian ini dapat dijadikan acuan dalam pemilihan model pembelajaran yang sesuai dengan Kurikulum 2013 dengan melihat karakteristik muatan pembelajaran yang terintegrasi, pendekatan saintifik serta kebutuhan siswa. Kegiatan pembelajaran pun menjadi lebih inovatif dan variatif karena dapat menggunakan model pembelajaran yang sesuai dengan Kurikulum 2013. Salah satu model pembelajaran yang dapat disarankan, yaitu model pembelajaran snowball throwing berbantuan media video terutama untuk kegiatan pembelajaran PPKn. (2) Bagi Siswa. Diterapkannya model pembelajaran snowball throwing berbantuan media video dalam penelitian ini, siswa menjadi aktif, bertanggung jawab, membentuk interaksi yang positif antar siswa dalam mengikuti proses pembelajaran serta mampu membangun pengetahuannya sendiri untuk mencapai hasil belajar yang optimal, khususnya pada kompetensi pengetahuan PPKn. (3) Bagi Kepala Sekolah. Berdasarkan hasil penelitian ini sekolah diharapkan dapat menciptakan kondisi yang mampu mendorong para guru untuk mencoba menerapkan model-model pembelajaran yang sesuai dengan karakteristik Kurikulum 2013 untuk meningkatkan kualitas proses pembelajaran disekolah. (4) Bagi Peneliti Lain . Peneliti lain agar mampu menemukan model pembelajaran yang lebih inovatif dan bervariasi yang sesuai dengan Kurikulum 2013 agar dapat memotivasi siswa untuk mengikuti kegiatan pembelajaran dengan baik. 


\section{Daftar Rujukan}

Agung, A. A. Gede. 2013. Evaluasi Pendidikan. Singaraja: Deepublish.

Agung, A. A. Gede. 2016. Statistika Dasar untuk Pendidikan. Yogyakarta: Deepublish.

Arikunto, Suharsimi. 2016. Dasar-Dasar Evaluasi Pendidikan. Jakarta: PT Bumi Aksara.

Cahyono, Tri. SKM. 2015. Statistik Uji Normalitas. Purwokerto: Yasamas.

Dantes, Nyoman. 2017. Desain Eksperimen dan Analisis Data. Depok: PT. RajaGrafindo Persada.

Huda, Miftahul. 2014. Model-model Pengajaran dan Pembelajaran. Yogyakarta: Pustaka Belajar.

Kosasih, E. 2014. Strategi Belajar dan Pembelajaran Implementasi Kulikulum 2013. Bandung: Yrama Widya.

Lestari, Karunia Eka dan Mokhammad Ridwan Yudhanegara. 2015. Penelitian Pendidikan Matematika.Cetakan Ke-1. Bandung: PT Refika Aditama.

Peraturan Menteri Pendidikan dan Kebudayaan Republik Indonesia Nomor 24 Pasal 2 ayat 1 Tentang Kompetensi Inti pada Kurikulum 2013, 2016. Jakarta: Kemendikbud.

Peraturan Menteri Pendidikan dan Kebudayaan Republik Indonesia Nomor 57 Lampiran III Tentang Karakteristik Pembelajaran Tematik Terpadu. 2014. Jakarta: Kemendikbud.

Peraturan Menteri Pendidikan dan Kebudayaan Republik Indonesia Nomor 81 Lampiran IV Tentang Pendekatan Saintifik .2013. Jakarta: Kemendikbud

Peraturan Menteri Pendidikan dan Kebudayaan Republik Indonesia Nomor 103 Tentang Pembelajaran pada Pendidikan Dasar dan Pendidikan Menengah, 2014. Jakarta: Kemendikbud.

Peraturan Menteri Pendidikan dan Kebudayaan Republik Indonesia Nomor 104 Tentang Penilaian Hasil Belajar oleh Pendidik pada Pendidikan Dasar dan Pendidikan Menengah, 2014. Jakarta: Kemendikbud.

Pribadi, A. 2017. Media \& Teknologi dalam Pembelajaran. Jakarta: Kencana.

Sani, Ridwan Abdullah. 2014. Inovasi Pembelajaran. Jakarta: PT Bumi Aksara.

Rangkuti, Anna Armeini. 2017. Statistika Inferensial untuk Psikologi dan Pendidikan. Jakarta: Kencana.

Setyosari, Punaji. 2015. Metode Penelitian Pendidikan dan Pengembangan. Jakarta: Prenadamedia Group.

Shoimin, Aris. 2014. 68 Model Pembelajaran Inovatif Dalam Kurikulum 2013. Yogyakarta: Ar-ruzz media.

Shoimatul, S. Ula. 2013. Revolusi Belajar. Jakarta: Ar-ruzz media.

Sudana, 2017. "Pengaruh Model Pembelajaran Kooperatif Tipe Snowball Throwing Berbantuan Media Power Point Terhadap Hasil Belajar IPA". Jurusan Pendidikan 
Guru Sekolah Dasar.Volume 5, Nomor 2 (hlm. - ).Tersedia pada https://ejournal.undiksha.ac.id/index.php/JJPGSD/article/view/10769 (diakses tanggal 03 Pebruari 2019).

Sudijono, Anas. 2013. Evaluasi Pendidikan. Jakarta : PT Raja Grafindo Persada.

Sugiyono. 2013. Statistika Untuk Penelitian. Bandung: Alfabeta.

Sugiyono. 2017. Metode Penelitian Kuantitatif, Kualitatif, dan R \& D.Bandung: Alfabeta.

Sukardi, 2004. Metodelogi Penelitian Pendidikan. Jakarta: PT Bumi Aksara.

Sukiman, 2012. Pengembangan Media Pembelajaran. Yogyakarta: PT Pustaka Insan Madani.

Supardi. 2015. Penilaian Autentik Pembelajaran Afektif, Kognitif, dan Psikomotor. Jakarta: Rajawali Pers.

Susiawan, 2013. "Pengaruh Strategi Guided Note Taking Berbantuan Media Video Terhadap Hasil Belajar IPS Siswa Kelas IV SD Desa Sari Mekar". Jurusan Pendidikan Guru Sekolah Dasar.Volume 1, Nomor - (hlm. --).Tersedia pada http://id.portalgaruda.org/index.php?ref=browse\&mod=viewarticle\&article=10 5600 (diakses tanggal 03 Pebruari 2019).

Undang Undang Republik Indonesia no. 20 tentang Sistem Pendidikan Nasional, 2003. Jakarta : Kemendikbud.

Wahyuni, 2013. "Pengaruh Pembelajaran Kontekstual Bermuatan Klarifikasi Nilai Terhadap Hasil Belajar PPKn Siswa Kelas IV SD Gugus 8 Kecamatan Mengwi, Kabupaten Badung Tahun Ajaran 2012/2013". Jurusan Pendidikan Guru Sekolah Dasar.Volume 1, Nomor - (hlm. --).Tersedia pada http://id.portalgaruda.org/index.php?ref=browse\&mod=viewarticle\&article=10 $\underline{5881}$ (diakses tanggal 03 Pebruari 2019 